\title{
Optimization of drilling process parameters on delamination factor of Jute reinforced unsaturated polyester composite using Box-Behnken design of experiment
}

\author{
Z. Mustafa ${ }^{1}$, N.H. Idrus ${ }^{1,2}$, A B. Mohd Hadzley ${ }^{1}$, D. Sivakumar ${ }^{3}$, M.Y. Norazlina', S.H.S.M. Fadzullah³ ${ }^{3}$ A. Anjang ${ }^{4}$, K. Thongkaew ${ }^{5}$ \\ ${ }^{1}$ Fakulti Kejuruteraan Pembuatan, Universiti Teknikal Malaysia Melaka, Hang Tuah Jaya, 76100 Durian Tunggal, Melaka, Malaysia. \\ 2 Department of Polymer Composite Processing Technology, Kolej Kemahiran Tinggi MARA, 76400 Masjid Tanah, Melaka, Malaysia. \\ ${ }^{3}$ Centre for Advanced Research on Energy, Fakulti Kejuruteraan Mekanikal, Universiti Teknikal Malaysia Melaka, Hang Tuah Jaya, \\ 76100 Durian Tunggal, Melaka, Malaysia. \\ ${ }^{4}$ School of Aerospace Engineering, Universiti Sains Malaysia, 14300, Malaysia. \\ ${ }^{5}$ Industrial Engineering Department, Faculty of Engineering, Prince Songkla University, Songkhla, 90112, Thailand.
}

\begin{abstract}
This paper presents an investigation on the influence of the drilling parameters such as feed rate, spindle speed and drill tool diameter onto the delamination factor of the jute reinforced unsaturated polyester composite. Natural fibre based composite are mostly used for commodity application and often subjected to drilling during applications and may generate delamination of drilled holes on the workpiece. The composite was fabricated using woven jute fibre via vacuum bagging method followed a high temperature curing using hot press. The fibre was kept at $40 \mathrm{vol}$. $\%$. The main effect and the interaction between the specified factors of feed rate $(20-100 \mathrm{~mm} / \mathrm{min})$, spindle speed (500-1500 rpm) and drill tool diameter $(4-8 \mathrm{~mm})$ with delamination factor as corresponding respond was structured via the Response Surface Methodology (RSM) based on three-level Box-Behnken design of experiment and the ANOVA. The levels of importance of the process parameters on flexural properties are determined by using Analysis of Variance (ANOVA). The optimised drilling process parameters obtained as $24.38 \mathrm{~mm} / \mathrm{min}$ of feed rate, $1146.14 \mathrm{rpm}$ of spindle speed and $5.51 \mathrm{~mm}$ drill tool diameter achieved the most minimal delamination factor. The feed rate and spindle speed were perceived as the most influential drilling parameters on the delamination factor of the jute reinforced unsaturated polyester composite.
\end{abstract}

ARTICLE HISTORY

Revised: $9^{\text {th }}$ Dec 2019

Accepted: 9th Dec 2019

\section{KEYWORDS}

Jute reinforced polymer

composite;

feed rate;

drill diameter;

spindle speed;

delamination factor;

Box-Behnken.

\section{INTRODUCTION}

Jute fibre is one of the widely used natural fibre that can be considered as an alternative reinforcement material to the synthetic fibreglass and carbon fibre owing to their relatively excellent specific mechanical properties, biodegradability, low production cost and low density [1,2]. Unsaturated polyester provides good dimensional stability and affordable cost [3].

Machining fibre reinforced composite materials is a complex process due to their heterogeneity, anisotropy, and high abrasiveness of fibres [4-6]. Often, conventional drilling process resulting in damage of the composite materials in the form of delamination, fibre pull-out, hole shrinkage, spalling, fuzzing and thermal degradation [7,8]. Although researchers have applied a variety of machining technologies such as laser machining or waterjet machining $[9,10]$ on the synthetic fibre composite materials, the conventional drilling technology (i.e. using a solid cutting tool) has been popularly used due to low machining cost and simplicity. As the fabrication process for jute reinforced composite is similar to that of synthetic fibre, it is possible that drilling induced-damage could also occur in this natural fibre based composites. The damage that occurred during the drilling process mainly influenced by the choice of process parameters, the geometry of the cutting tool and the nature of composite materials [5]. Among these, the most common damage is delamination, which is the most profound damage in drilling process [9,11]. As the delamination formed on the machined workpiece, the structural integrity of the material is reduced. The formation of delamination is caused by the complex interaction between the cutting tool and the anisotropic property of the composites [12]. Drilling induced-delamination normally occurs both at the entrance and the exit holes. The tool geometry and machining parameters have been recognized as the major contributor to the delamination damage during the drilling process [13].

It has been well documented that the thrust force, which is primarily a function of feed rate and tool geometry, are the main cause of delamination [14]. Apart from this, other parameters in inducing the delamination by drilling included feed rate, spindle speed and the diameter of the drilling tool [15]. In addition, type of drilling tools, ranging from the angle of tool, materials, number of flutes may also affect the delamination of the composite materials.

Therefore, it is crucial to determine the optimum drilling parameters for the reinforced polyester resin jute composite laminates. The optimization study will predict the best feed rate, spindle speed and the diameter for producing minimal delamination and preventing the formation of failure from drilling. These drilling process parameters are chosen as specified factors as they largely influence the delamination factor of drilled composites [8,16,17]. Drilling of composite laminates imposes special demands on the geometry and the wear resistance of the drill bit. Besides, twist drill bit, several 
special drill bits such as step drill bit, brad point drill bit, slot drill bit, and straight-flute drill bit are developed for drilling of composite laminates to reduce drilling-induced delamination. Other than that, the tool geometry includes the number flute of the drill, in which 4-flute drill bit produced less delamination compared to the 2-flute drill bit. Moreover, it was observed that the angle of cut also affects the delamination produced. The optimization is conducted using Box-Behnken and ANOVA.

\section{METHODOLOGY}

\section{Materials}

The jute fibre in the form of woven mat is nearly odourless, light brown in colour is supplied by Composite Evolution from UK under trade name Biotex-Jute. Unsaturated polyester resin (PCCR 733-6544) is used as a matrix and supplied by Revertex Sdn. Bhd. The hardener used in the composite is MEKP (Methyl Ethyl Ketone Peroxide). The properties of the materials are shown in Table 1.

Table 1. Physical, mechanical, and thermal properties of raw materials.

\begin{tabular}{ccc}
\hline Properties & Jute & Polyester \\
\hline Density & $1.3 \mathrm{~g} / \mathrm{cm}^{3}$ & $1.09 \mathrm{~g} / \mathrm{cm}^{3}$ \\
Tensile strength & $393 \mathrm{MPa}$ & $40 \mathrm{MPa}$ \\
Melting point & $230^{\circ} \mathrm{C}$ & $54^{\circ} \mathrm{C}$ \\
\hline
\end{tabular}

\section{Pre-treatment}

The raw jute fibres were treated in $5 \% \mathrm{NaOH}$ as detailed in [18]. The fibres were then cleaned several times with distilled water followed by immersion in a very dilute hydrochloric acid until the $\mathrm{pH}$ reached $\mathrm{pH}$ 7. Finally, the fibres were again washed several times with distilled water and dried in a drying oven at $70^{\circ} \mathrm{C}$ overnight.

\section{Composite fabrication}

The jute mat was hand lay-up in a $300 \mathrm{~mm}$ x $300 \mathrm{~mm}$ x $3 \mathrm{~mm}$ mould by maintaining the fibre volume fraction of 0.4 . The unsaturated Polyester resin was mixed with MEKP hardener at a factor suggested by the manufacturer and was poured into the mould and distributed by using brushes followed by vacuum bagging for 2 hours. The mould was compressed moulded under $3.5 \mathrm{MPa}$ pressure at $168^{\circ} \mathrm{C}$ for 20 minutes using parameters optimised in our previous study [19].

\section{Drilling process}

Drilling of the jute fibre reinforced polyester composites was done using a Computer Numeric Control (CNC) MAHO Vertical Machining Centre (XD-40A). The machine centre has a maximum spindle speed of $5000 \mathrm{rpm}$ with a table size of 1270 x $254 \mathrm{~mm}$. The experiments were carried out using a standard high-speed steel twist drill bit with $4 \mathrm{~mm}, 6 \mathrm{~mm}$ and $8 \mathrm{~mm}$ in diameter supplied by Sandvik (Germany). The range of diameter used is based on the thickness of the composite panel factor with the diameter of the tool. The factor of 1: 3 correspond to the thickness of $1 \mathrm{~mm}$ to $3 \mathrm{~mm}$ diameter of the drill bit. A program is written in G-codes to drill 5 holes for all of the runs with the parameters changing. The parameters are the feed rate $(\mathrm{mm} / \mathrm{min})$, spindle speed (RPM) and the drill diameter $(\mathrm{mm})$. Delamination size was measured using the Microscopy SRF and the data tabulated.

\section{Delamination Factor}

Delamination is found both at the hole entry and hole exit. The entry region caused by peel-up force from the cutting tool whiles the exit region caused by push-out force [20]. The delamination at the entry hole is more severe than the exit hole because of the larger thrust force. Therefore, in this study, the delamination generated associated with the drilling process is observed only are at the entrance of the drill hole. The delamination factor around the holes, the maximum diameter $\left(D_{\max }\right)$ in the delamination zone was measured as shown in Figure 1. 


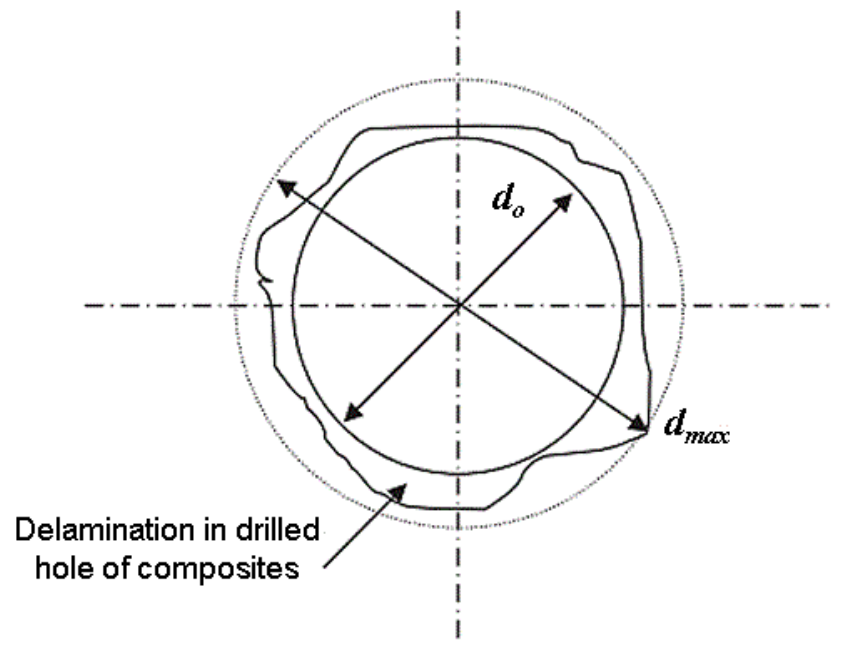

Figure 1: Schematic diagram showing the measurement of delamination diameter, $d$, induced by drilling of composites [21].

The value of delamination factor $\left(F_{d}\right)$ can be determined by the following Equation. (1).

$$
F_{d}=\frac{D_{\max }}{d}
$$

In which, $D_{\max }$ is the maximum diameter of the delamination zone in $\mathrm{mm}$ and $d$ is the diameter of the drill in $\mathrm{mm}$. Therefore, the optimum delamination is the delamination factor that is close or equal to $F_{d}=1.00$.

\section{Optimisation by Response Surface Methodology (RSM)}

The impact of specified drilling process parameters is studied using Response Surface Methodology (RSM) based on the three-level Box-Behnken design of the experiment. The feed rate, spindle speed and tool diameters were assessed at three levels: $-1,0$, and +1 as presented in Table 2 . A total of 17 experiments (Table 3 ) were executed with 3 replications for the optimization process.

Table 2. Process parameters and their actual values for the coded values in the experimental. design.

\begin{tabular}{cccc}
\hline \multirow{2}{*}{ Process parameters } & \multicolumn{3}{c}{ Levels } \\
\cline { 2 - 4 } & +1 level & 0 level & -1 level \\
\hline Feed Rate $(\mathrm{mm} / \mathrm{min})$ & 20 & 60 & 100 \\
Spindle Speed (rpm) & 500 & 1000 & 1500 \\
Tool Diameter $(\mathrm{mm})$ & 4 & 6 & 8 \\
\hline
\end{tabular}

Table 3. Three-factor Box-Behnken design experiment with the predicted response of the dependent variable (delamination factor).

\begin{tabular}{cccc}
\hline Runs & $\begin{array}{c}\text { Factor 1 } \\
\text { A: Feed Rate } \\
\text { mm/min }\end{array}$ & $\begin{array}{c}\text { Factor } 2 \\
\text { B: Spindle Speed } \\
\text { rpm }\end{array}$ & $\begin{array}{c}\text { Factor 3 } \\
\text { C: Tool Diameter } \\
\text { mm }\end{array}$ \\
\hline 1 & 60.00 & 1000.00 & 6.00 \\
2 & 20.00 & 1500.00 & 6.00 \\
3 & 60.00 & 1000.00 & 6.00 \\
4 & 60.00 & 1500.00 & 4.00 \\
5 & 20.00 & 500.00 & 6.00 \\
6 & 20.00 & 1000.00 & 8.00 \\
7 & 100.00 & 500.00 & 6.00 \\
8 & 20.00 & 1000.00 & 4.00 \\
9 & 60.00 & 1500.00 & 8.00 \\
10 & 60.00 & 1000.00 & 6.00 \\
11 & 100.00 & 1000.00 & 8.00 \\
12 & 100.00 & 1500.00 & 6.00 \\
13 & 60.00 & 1000.00 & 6.00 \\
14 & 60.00 & 500.00 & 8.00 \\
15 & 60.00 & 500.00 & 4.00 \\
\hline
\end{tabular}




\begin{tabular}{cccc}
\hline 16 & 60.00 & 1000.00 & 6.00 \\
17 & 100.00 & 1000.00 & 4.00 \\
\hline
\end{tabular}

\section{Statistical Analysis and Modelling}

The level of importance of the process parameters on flexural properties is determined by using analysis of variance (ANOVA). The main effects and their interactions are analysed in the cubic model with delamination factor as the corresponding respond. The statistical software package, Design Expert 9 (Stat Ease, Inc., Minneapolis, MN, USA), was used for the regression analysis of the experimental data and also to plot the three-dimensional response surface graphs. The multiple coefficients of correlation $R$ and the determination coefficient of correlation $R^{2}$ were calculated to evaluate the performance of the regression equation [22]. The point optimization method was employed in order to optimize the level of each variable for minimum response.

\section{RESULTS AND DISCUSSION}

\section{Effect of Drilling Process Parameters on Delamination Factor}

The effect of drilling parameters on delamination factor in drilling jute fibre reinforced composites are presented in terms of the delamination factor against spindle speed (Figures 2 and 3. Figure 2 shows the effect of drill tool diameter with respect to the different spindle speed on delamination factor. The figure indicates that the increase of drill tool diameter increases the delamination factor; on the other hand, the increase of spindle speed reduces the delamination factor in drilling processes. The increase of drill tool diameter increases the load on the tool and contact between the work-piece and tool, which increase the delamination. In the other hand, as the spindle speed increase, the was a reduction in delamination factor. This observation might due to softening of the matrix at the drilling site due to heat generated by tool friction resulting in easier removal of the matrix.

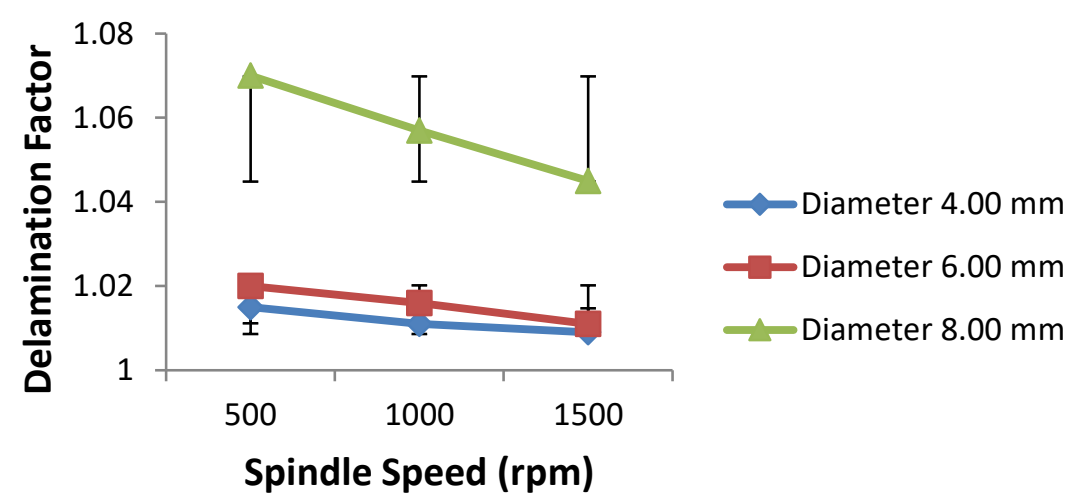

Figure 2. Effect of drill diameter with respect to the spindle speed on delamination factor.

Figure 3 shows the effect of drill tool diameter with respect to different feed rate on their delamination factor. It was found that increasing the feed rate results in an increase in the delamination factor in drilling. The drill tool diameter is a major influence in the drilling of composite materials. An increase in the drill tool diameter and feed rate increases the contact between the workpiece hole and load on the tool, which in turn increases the delamination factor. Therefore, this implies that by using optimized drilling parameters, the delamination in drilling can be reduced.

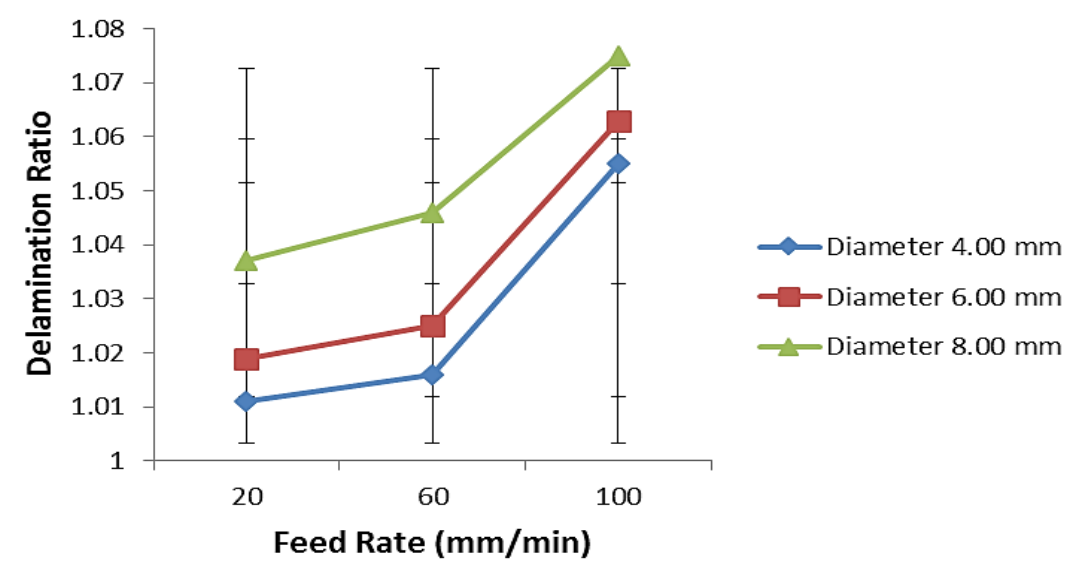

Figure 3. Effect of drill diameter with respect to the feed rate on delamination factor. 


\section{Statistical Analysis of Response Studied}

The optimum conditions for feed rate, spindle speed and tool diameter of the drilling process were determined by means of the Box- Behnken of RSM. The overall results are shown in Table 4. The obtained responses were varied between 1.011 and 1.107 delamination factor. Generally, from the results obtained, it is revealed that it is necessary to employ the highest possible spindle speed with lower values of feed rate and tool diameter for minimizing the delamination in the drilling process of composite materials. However, the relative importance among the drilling process parameters requires the use of ANOVA analysis.

Table 4. Three-factor Box-Behnken design experiment with the predicted response of delamination factor.

\begin{tabular}{|c|c|c|c|c|}
\hline \multirow{2}{*}{ Runs } & Factor 1 & Factor 2 & Factor 3 & Response 1 \\
\hline & $\begin{array}{l}\text { A: Feed Rate } \\
\mathrm{mm} / \mathrm{min}\end{array}$ & $\begin{array}{l}\text { B: Spindle Speed } \\
\text { rpm }\end{array}$ & $\begin{array}{c}\text { C: Tool Diameter } \\
\mathrm{mm}\end{array}$ & $\begin{array}{c}\text { Delamination } \\
\text { Factor }\end{array}$ \\
\hline 1 & 60.00 & 1000.00 & 6.00 & 1.02 \\
\hline 2 & 20.00 & 1500.00 & 6.00 & 1.011 \\
\hline 3 & 60.00 & 1000.00 & 6.00 & 1.017 \\
\hline 4 & 60.00 & 1500.00 & 4.00 & 1.074 \\
\hline 5 & 20.00 & 500.00 & 6.00 & 1.083 \\
\hline 6 & 20.00 & 1000.00 & 8.00 & 1.037 \\
\hline 7 & 100.00 & 500.00 & 6.00 & 1.145 \\
\hline 8 & 20.00 & 1000.00 & 4.00 & 1.019 \\
\hline 9 & 60.00 & 1500.00 & 8.00 & 1.046 \\
\hline 10 & 60.00 & 1000.00 & 6.00 & 1.02 \\
\hline 11 & 100.00 & 1000.00 & 8.00 & 1.075 \\
\hline 12 & 100.00 & 1500.00 & 6.00 & 1.057 \\
\hline 13 & 60.00 & 1000.00 & 6.00 & 1.02 \\
\hline 14 & 60.00 & 500.00 & 8.00 & 1.07 \\
\hline 15 & 60.00 & 500.00 & 4.00 & 1.092 \\
\hline 16 & 60.00 & 1000.00 & 6.00 & 1.02 \\
\hline 17 & 100.00 & 1000.00 & 4.00 & 1.107 \\
\hline
\end{tabular}

The ANOVA is a statistically based objective decision-making tool, which helps in testing the significance of the parameters by comparing the mean square against an estimate of the experimental errors at specified confidence levels. The ANOVA for response surface cubic model of specified parameters to test their adequacy are summarized in Table 5, evaluated by the regression coefficients, $F$-values, $p$ values, correlation coefficient $(R)$, and the determination coefficient $\left(R^{2}\right)$. Generally, the proposed model is highly suggested to be significant as the p-value less than 0.0001 . All specified parameters also individually affect significantly the corresponding respond as p-value is less than 0.0001 . A larger Fvalue indicates that the variation of process parameter makes a significant change in the quality characteristic. The Model F-value of 1106.13 implies the model is significant. There is only a $0.01 \%$ chance that a "Model F-value" this large could occur due to noise. It can be observed in Table 5, feed rate shows the highest F-value followed by tool diameter and spindle speed, means that it is the most significant drilling process parameter in minimizing the delamination effect of composite materials. The coefficient of determination value $\left(R^{2}=0.9997\right)$ indicates that the response model can explain about $99 \%$ of the total variations. Additionally, the coefficient of adjusted determination value (Adj $R^{2}=0.9988$ ) is also high enough to indicate the significance of the selected model.

In this case, the individual effects of $\mathrm{A}, \mathrm{B}, \mathrm{C}, \mathrm{A}^{2}, \mathrm{~B}^{2}$ and $\mathrm{C}^{2}$ are significant model terms. Also, significant $p$ value (, 0.05 ) was found for the interaction $(\mathrm{AB}$ and $\mathrm{AC}$ ) between the design factor. Hence, it can be concluded that the feed rate (A), spindle speed (B) and the tool diameter (C) had a significant positive effect individually on minimizing delamination response in the drilling process. This model can be used to navigate the design space.

A proposed second degree polynomial was fitted to the data presented in ANOVA using multiple linear regressions to determine the optimum conditions that resulted in the optimize delamination factor. By applying multiple regression analysis on the experimental data, the following second degree polynomial was obtained:

Delamination at entrance $=1.02+0.032 * \mathrm{~A}-0.011 * \mathrm{~B}-0.012 * \mathrm{C}-4.000 \mathrm{X} 10^{-3} * \mathrm{~A} * \mathrm{~B}-0.013 * \mathrm{~A} * \mathrm{C}-1.500 \mathrm{X}$ $10^{-3} * \mathrm{~B} * \mathrm{C}+0.022 * \mathrm{~A}^{2}+0.033 * \mathrm{~B}^{2}+0.018 * \mathrm{C}^{2}-0.029 * \mathrm{~A}^{2} * \mathrm{~B}+9.000 \mathrm{X} 10^{-3} * \mathrm{~A}^{2} * \mathrm{C}-4.500 \mathrm{X} 10^{-3} * \mathrm{~A} * \mathrm{~B}^{2}$ 
Table 5. ANOVA for response surface cubic model of delamination factor.

\begin{tabular}{|c|c|c|c|c|c|c|}
\hline Source & $\begin{array}{l}\text { Sum of } \\
\text { Squares }\end{array}$ & df & $\begin{array}{l}\text { Mean } \\
\text { Square }\end{array}$ & $\begin{array}{l}\mathrm{F} \\
\text { Value }\end{array}$ & $\begin{array}{l}\mathrm{p} \text {-value } \\
\text { Prob > F }\end{array}$ & \\
\hline Model & 0.024 & 12 & $1.991 \mathrm{E}-003$ & 1106.13 & $<0.0001$ & significant \\
\hline A-Feed Rate & 3.969E-003 & 1 & 3.969E-003 & 2205.00 & $<0.0001$ & \\
\hline B-Spindle Speed & 4.410E-004 & 1 & 4.410E-004 & 245.00 & $<0.0001$ & \\
\hline C-Tool Diameter & $6.250 \mathrm{E}-004$ & 1 & $6.250 \mathrm{E}-004$ & 347.22 & $<0.0001$ & \\
\hline $\mathrm{AB}$ & $6.400 \mathrm{E}-005$ & 1 & $6.400 \mathrm{E}-005$ & 35.56 & 0.0040 & \\
\hline $\mathrm{AC}$ & $6.250 \mathrm{E}-004$ & 1 & $6.250 \mathrm{E}-004$ & 347.22 & $<0.0001$ & \\
\hline $\mathrm{BC}$ & $9.000 \mathrm{E}-006$ & 1 & $9.000 \mathrm{E}-006$ & 5.00 & 0.0890 & \\
\hline $\mathrm{A}^{2}$ & $2.001 \mathrm{E}-003$ & 1 & $2.001 \mathrm{E}-003$ & 1111.67 & $<0.0001$ & \\
\hline $\mathrm{B}^{2}$ & $4.530 \mathrm{E}-003$ & 1 & $4.530 \mathrm{E}-003$ & 2516.58 & $<0.0001$ & \\
\hline $\mathrm{C}^{2}$ & $1.410 \mathrm{E}-003$ & 1 & $1.410 \mathrm{E}-003$ & 783.37 & $<0.0001$ & \\
\hline $\mathrm{ABC}$ & 0.000 & 0 & & & & \\
\hline $\mathrm{A}^{2} \mathrm{~B}$ & $1.740 \mathrm{E}-003$ & 1 & $1.740 \mathrm{E}-003$ & 66.94 & $<0.0001$ & \\
\hline $\mathrm{A}^{2} \mathrm{C}$ & $1.620 \mathrm{E}-004$ & 1 & $1.620 \mathrm{E}-004$ & 90.00 & 0.0007 & \\
\hline $\mathrm{AB}^{2}$ & 4.050E-005 & 1 & 4.050E-005 & 22.50 & 0.0090 & \\
\hline $\mathrm{AC}^{2}$ & 0.000 & 0 & & & & \\
\hline $\mathrm{B}^{2} \mathrm{C}$ & 0.000 & 0 & & & & \\
\hline $\mathrm{BC}^{2}$ & 0.000 & 0 & & & & \\
\hline$A^{3}$ & 0.000 & 0 & & & & \\
\hline $\mathrm{B}^{3}$ & 0.000 & 0 & & & & \\
\hline $\mathrm{C}^{3}$ & 0.000 & 0 & & & & \\
\hline Pure Error & 7.200E-006 & 4 & $1.800 \mathrm{E}-006$ & & & \\
\hline Cor Total & 0.024 & 16 & & & & \\
\hline Std. Dev. & $1.342 \mathrm{E}-003$ & R-S & & 0.9997 & & \\
\hline Mean & 1.05 & $\operatorname{Adj}$ & uared & 0.9988 & & \\
\hline C.V. $\%$ & 0.13 & Pre & juared & N/A & & \\
\hline PRESS & N/A & Ade & cision & 114.215 & & \\
\hline
\end{tabular}

\section{Optimisation of the Delamination Factor in the Drilling of Jute Fibre Reinforced Composite}

The best way in optimizing the parameters that influence the delamination factor with the desirability value of 1.00 is by generating the 3D Response Surface Model (RSM) in which the contour in the surface plots from the regression model and optimize the variables. The 3D plots were generated by having one constant variable at the centre point and varying the others within the range. By doing so, the effects on the drilling process by the feed rate; spindle speed and the tool diameter on the delamination factor can be sought. Figure 4 shows the 3D RSM and contour plot of feed rate and spindle speed interaction effect in which the tool diameter is assumed to be a constant. The analysis of the 3D surface indicates that in the drilling process, the optimum delamination factor with the desirability of 1.00 can be achieved by using the spindle speed in the range of $750 \mathrm{rpm}$ until $1500 \mathrm{rpm}$ at the lowest feed rate of $20.00 \mathrm{~mm} / \mathrm{min}$ to $70.00 \mathrm{~mm} / \mathrm{min}$. It was observed from the diagram that the delamination factor is not at its desired value if the spindle speed was increased up to $500 \mathrm{rpm}$ when using a feed rate of $100.00 \mathrm{~mm} / \mathrm{min}$. The 3D surface also shows the values of spindle speed relative to the feed rate in obtaining the desired delamination factor represented by the dark blue coloured zone. The optimum conditions for both can be obtained from the contour diagram in Figure 4(b).

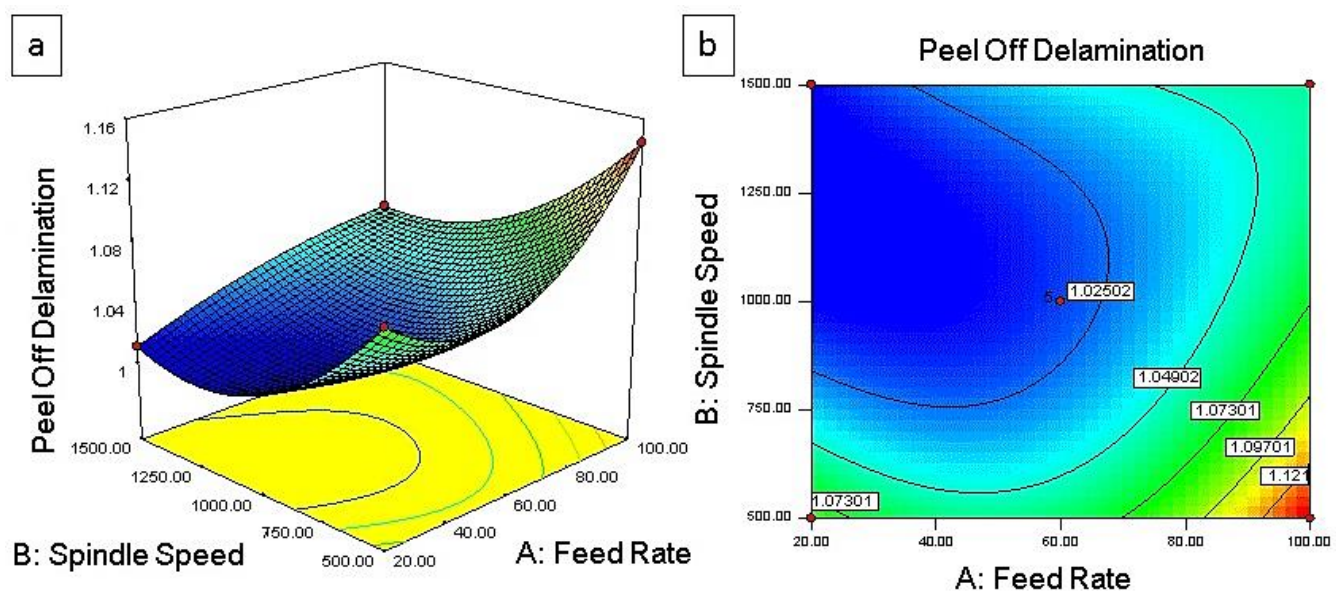

Figure 4. 3D response surface plot of peel off delamination; (a) coupled with its contour plots (b) as a function of feed rate and spindle speed. 
It was observed that by increasing the spindle speed accompanied by a reduction in the feed rate yields in delamination factor of 1.025 , closest to the optimum delamination required, that is 1.00 . The parameters for the optimum delamination is at $20.00 \mathrm{~mm} / \mathrm{min}$ to $60.00 \mathrm{~mm} / \mathrm{min}$ feed rate and $750 \mathrm{rpm}$ to $1000 \mathrm{rpm}$ spindle speed using the $6.00 \mathrm{~mm}$ diameter drilling tool. The analysis of the 3D surface indicates that in the drilling process, the optimum Delamination Factor with Desirability of 1.00, thus requiring a reduction in the feed rate to a range between $20.00 \mathrm{~mm}$ and $60.00 \mathrm{~mm}$, as we need to select a drilling tool with a diameter between $5.00 \mathrm{~mm}$ and $7.00 \mathrm{~mm}$. This implies that the desired value of the delamination factor is 1.025 . The precise value of the optimum condition for both can be obtained from the contour diagram in Figure 4b.

The effect of feed rate and tool diameter on the delamination factor of the composite is presented in Figure 5. From the trend, it was observed that by reducing the feed rate with selecting the tool diameter between $5.00 \mathrm{~mm}$ to $7.00 \mathrm{~mm}$ and feed rate from $20.00 \mathrm{~mm} / \mathrm{min}$ to $60.00 \mathrm{~mm} / \mathrm{min}$ yields the delamination factor of 1.025 which is closest to 1.00 . The optimum spindle speed for these ranges is at $1000 \mathrm{rpm}$. The analysis of the 3D surface indicates that in the drilling process, the optimum delamination factor with the desirability of 1.00 can be achieved by selecting a drilling tool with the diameter between $5.00 \mathrm{~mm}$ and $7.00 \mathrm{~mm}$ and spindle speed between $750 \mathrm{rpm}$ to $1250 \mathrm{rpm}$, consequently yielded optimised delamination factor of 1.028. The precise value of the optimum condition for both can be obtained from the contour diagram in Figure 5b.
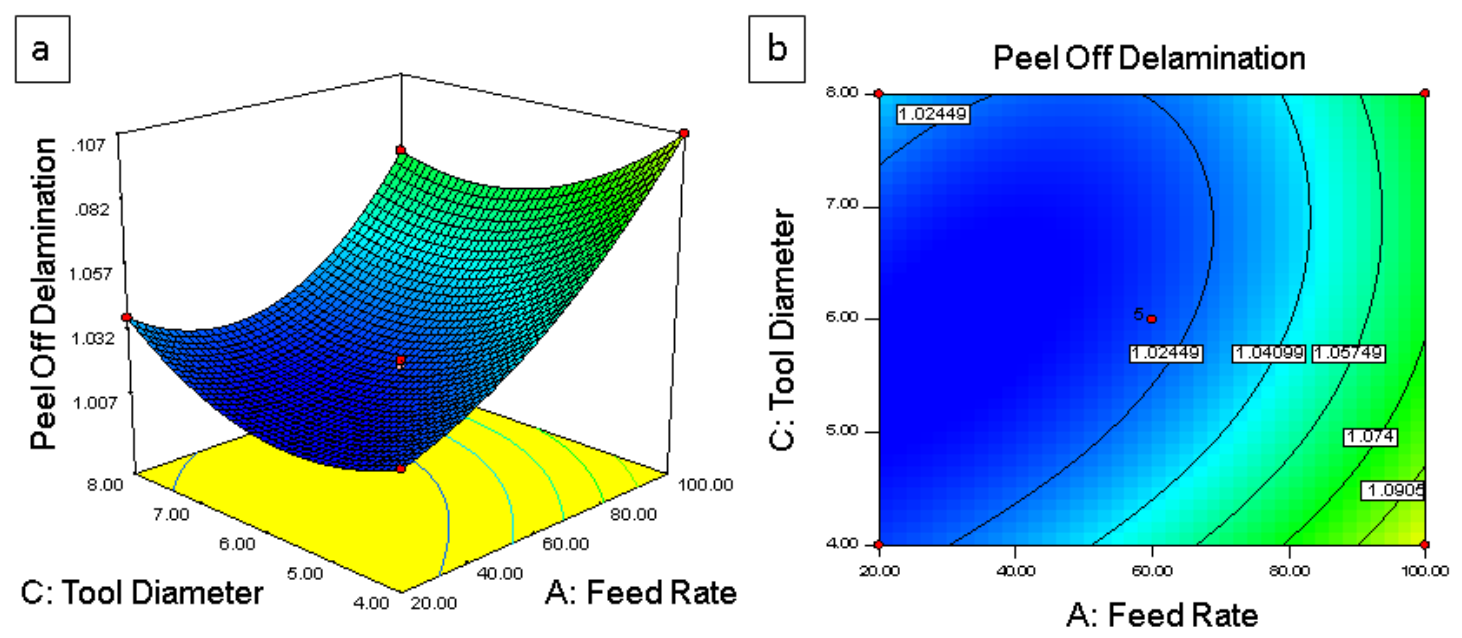

Figure 5. 3D response surface plot of peel off delamination (a) coupled with its contour plots (b) as a function of feed rate and tool diameter.

The effect of spindle speed and tool diameter on the Delamination factor of the composite coupled with its contour plot are presented in Figures 6 . The trend observed that by increasing the spindle speed with selecting the tool diameter between $5.00 \mathrm{~mm}$ and $7.00 \mathrm{~mm}$ yields the delamination factor of 1.028 which is closest to 1.00 . The optimum feed rate at the required points is at $60.00 \mathrm{~mm} / \mathrm{min}$. In order to select the optimum conditions and their respective levels, the model was analysed. The minimum response of Delamination factor of the composite was predicted at 1.000. The final optimised process parameters through magnified contour analysis are obtained as $60.00 \mathrm{~mm} / \mathrm{min}$ of feed rate, $1000.00 \mathrm{rpm}$ of spindle speed and $6.00 \mathrm{~mm}$ drill tool diameter.
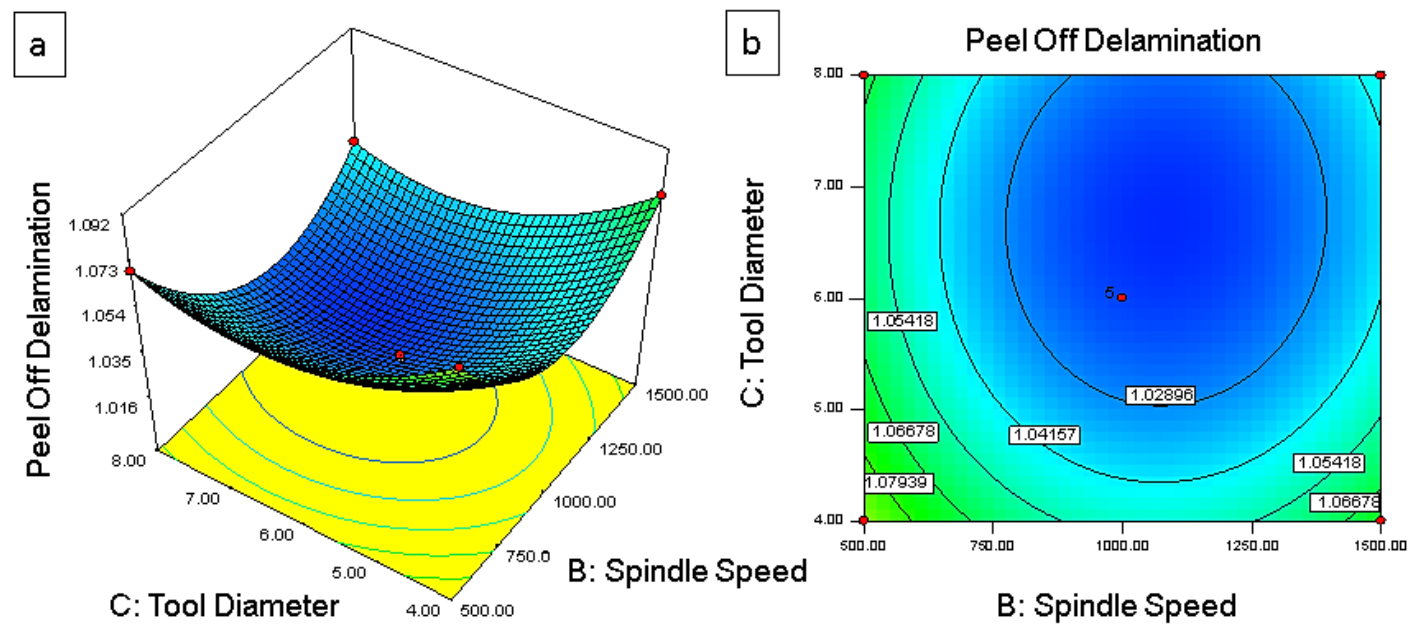

Figure 6. 3D response surface plot of peel off delamination (a) coupled with its contour plots

(b) as a function of spindle speed and tool diameter. 


\section{CONCLUSIONS}

The effects of drilling process parameters on the delamination factor of jute fibre reinforced composites are experimentally investigated. From the findings, it can be concluded that the feed rate and spindle speed have the most significant effect on delamination factor of the composite material. The diameter gives a minor effect, however, nonnegligible, as it is better to compare with bigger drill tool diameter.

In summary, it can be concluded that:

1. It is feasible to use of 3D response surface methodology in optimization and contour diagram in the selected process parameters feed rate, spindle speed and tool diameter for obtaining the minimum delamination factor or delamination damages of the jute composite material.

2. The delamination factor is highly influenced by the feed rate and the spindle speed and the tool diameter.

3. The cubic regression model was formed with the inclusion of the mentioned process using the Box-Behnken Design of Experiments and the ANOVA.

4. The combination of process parameters for a delamination factor at its minimum of 1.025 given at $60.00 \mathrm{~mm} / \mathrm{min}$ of feed rate, $1000.00 \mathrm{rpm}$ of spindle speed and $6.00 \mathrm{~mm}$ drill tool diameter were used.

\section{ACKNOWLEDGEMENTS}

The authors are grateful to Majlis Amanah Rakyat (MARA) for financial funding and Mr Mohd Effendi in Manufacturing Department of Kolej Kemahiran Tinggi MARA, Masjid Tanah for the technical assistance.

\section{REFERENCES}

[1] Ahsan Q, Carron TSS, Mustafa Z. On the use of nano fibrillated kenaf cellulose fiber as reinforcement in polylactic acid biocomposites. Journal of Mechanical Engineering and Sciences, 2019; 13(2): 4970-4988.

[2] Ismail AE, Aziz CA, Aswadi M. Tensile strength of woven yarn kenaf fiber reinforced polyester composites. Journal of Mechanical Engineering and Sciences, 2015; 9: 1695-1704.

[3] Akil HM, Santulli C, Sarasini F, Tirillò J, Valente T. Environmental effects on the mechanical behaviour of pultruded jute/glass fibre-reinforced polyester hybrid composites. Composites Science and Technology. 2014; 94: 62-70.

[4] Sunny T, Babu J, Philip J. Experimental Studies on Effect of Process Parameters on Delamination in Drilling GFRP Composites Using Taguchi Method. Procedia Material Science. 2014; 6: 1131-1142.

[5] Rezghi Maleki H, Hamedi M, Kubouchi M, Arao Y. Experimental study on drilling of jute fibre reinforced polymer composites. Journal of Composite Materials. 2019; 53(3): 283-295.

[6] Kumarasamy S, Abidin MSZ, Bakar MA, Nazida MS, Mustafa Z, Anjang A. Effects of high and low temperature on the tensile strength of glass fiber reinforced polymer composites, IOP Conference Series: Materials Science and Engineering. 2018; 370(1): 012021.

[7] Jauhari N, Mishra R, Thakur H. Natural fibre reinforced composite laminates-a review. Materials Today: Proceedings, 2015; 2(4-5): 2868-2877.

[8] Kavad BV, Pandey AB, Tadavi MV, Jakharia HC. A review paper on effects of drilling on glass fibre reinforced plastic. Procedia Technology, 2014; 14: 457- 464.

[9] Ramesh M, Palanikumar K, Reddy KH. Influence of tool materials on thrust force and delamination in drilling sisal-glass fibrereinforced polymer (S-GFRP) composites. Procedia Materials Science, 2014; 5:1915-1921.

[10] Deepak D, Pai A. Study on abrasive water jet drilling for graphite filled glass/epoxy laminates. Journal of Mechanical Engineering and Sciences, 2019: 13(2): 5126-5136.

[11] Aslan Z, Daricik F. Effects of multiple delaminations on the compressive, tensile, flexural, and buckling behaviour of Eglass/epoxy composites. Composites Part B: Engineering, 2016; 100:186-196.

[12] Kilickap E. Determination of optimum parameters on delamination in drilling of GFRP composites by Taguchi method. Indian Journal of Engineering Materials Science, 2010; 17(4): 265-274.

[13] Karnik SR. Delamination analysis in high-speed drilling of carbon fibre reinforced plastics (CFRP) using artificial neural network model. Material \& Design, 2008; 29: 1768 - 1776.

[14] Nasir AA, Azmi AI, Khalil ANM. Measurement and optimisation of residual tensile strength and delamination damage of drilled flax fibre reinforced composites. Measurement, 2015; 75: 298-307.

[15] Pickering KL, Efendy MA, Le TM. A review of recent developments in natural fibre composites and their mechanical performance. Composites Part A: Applied Science and Manufacturing, 2016; 83: 98-112.

[16] Prakash S, Mercy JL, Salugu MK, Vineeth KSM. Optimization of drilling characteristics using grey relational analysis (GRA) in medium density fibre board (MDF). Materials Today: Proceedings, 2015; 2(4-5): 1541-1551.

[17] Li N, Li Y, Zhou J, He Y, Hao X. Drilling delamination and thermal damage of carbon nanotube/carbon fibre reinforced epoxy composites processed by microwave curing. International Journal of Machine Tools and Manufacture, 2015: 97: 11-17.

[18] Ramli SNR, Fadzullah SHSM, Mustafa Z. The effect of alkaline treatment and fibre length on pineapple leaf fibre reinforced polylactic acid biocomposite. Jurnal Teknologi, 2017; 79(5-2): 111-115. 
[19] Mustafa Z, Idrus NH, Fadzullah SHSM, Hadzley AB, Shamsudin Z, Razali NSAM, Omar NI. Influence of Curing Temperature on Mechanical Properties of Woven Jute Reinforced Polyester Composite. Journal of Advanced Manufacturing Technology, 2018; 12(1(2)): 451-460.

[20] Faraz A. Cutting Edge Rounding: An Innovative Tool Wear Criterion in Drilling CFRP Composite Laminates. International Journal of Machine Tools \& Manufacturing, 2009; 49, (15): 1185-1196.

[21] Gaitonde VN, Karnik SR, Rubio JC, Correia AE, Abrão AM, Davim JP. A study aimed at minimizing delamination during drilling of CFRP composites. Journal of Composite Materials, 2011; 45(22): 2359-2368.

[22] Mohamad Yatim N, Shaaban A, Dimin MF, Yusof F, Abd Razak J. Application of response surface methodology for optimization of urea grafted multiwalled carbon nanotubes in enhancing nitrogen use efficiency and nitrogen uptake by paddy plants. Journal of Nanotechnology, 2016: 1-14. 